\title{
Critical Care Management of Acute Spinal Cord Injury-Part II: Intensive Care to Rehabilitation
}

\author{
Amanda Sacino $^{1}$ Kathryn Rosenblatt ${ }^{2,3}$ \\ ${ }^{1}$ Department of Neurosurgery, Johns Hopkins University School of \\ Medicine, Baltimore, Maryland, United States \\ 2Department of Anesthesiology and Critical Care Medicine, Johns \\ Hopkins University School of Medicine, Baltimore, Maryland, \\ United States \\ ${ }^{3}$ Department of Neurology, Johns Hopkins University School of \\ Medicine, Baltimore, Maryland, United States
}

\begin{abstract}
Address for correspondence Kathryn Rosenblatt, MD, MHS, Department of Anesthesiology and Critical Care Medicine, Johns Hopkins University School of Medicine, 600 N Wolfe Street, Phipps 455, Baltimore, MD 21287, United States (e-mail: krosenb3@jhmi.edu).
\end{abstract}

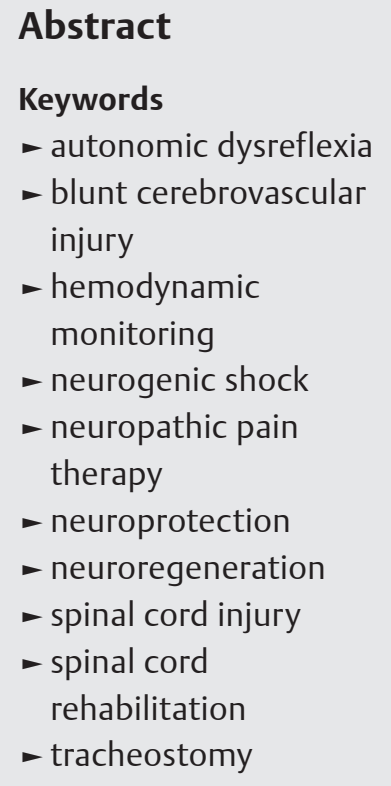

Spinal cord injury is devastating to those affected due to the loss of motor and sensory function, and, in some cases, cardiovascular collapse, ventilatory failure, and bowel and bladder dysfunction. Primary trauma to the spinal cord is exacerbated by secondary insult from the inflammatory response to injury. Specialized intensive care of patients with acute spinal cord injury involves the management of multiple systems and incorporates evidence-based practices to reduce secondary injury to the spinal cord. Patients greatly benefit from early multidisciplinary rehabilitation for neurologic and functional recovery. Treatment of acute spinal cord injury may soon incorporate novel molecular agents currently undergoing clinical investigation to assist in neuroprotection and neuroregeneration.

\section{Introduction}

In part I of this review, we first highlighted trends in the global epidemiology of acute spinal cord injury (SCI). We then summarized the mechanisms of primary injury and illustrated the cascade of biomolecular changes, called "secondary injury," linked to the body's inflammatory response to the initial trauma. We next summarized best practices for early assessment and resuscitation of SCI patients during initial presentation using the ABCDE (Airway, Breathing, Circulation, Disability, Exposure) approach as well as evidence-based recommendations for the timing of surgical decompression. We concluded with suggestions for anesthesia management during surgery for $\mathrm{SCI}$ to help mitigate secondary injury and optimize surgical outcomes. In this second part, we provide a systems-based review of critical care management, beginning with cardiovascular concerns. We then discuss recovery and rehabilitation efforts initiated in the intensive care unit (ICU) and conclude by reviewing promising neuroprotective approaches and neuroregenerative therapies.

\section{Intensive Care Unit Management of Neurologic Injury and Its Sequelae}

\section{Cardiovascular}

Acute SCI is associated with life-threatening cardiovascular complications that require heightened vigilance and preventive management in the ICU. Patients are at risk of neurogenic shock, unstable arrhythmias, and autonomic dysreflexia (AD) for weeks to months after injury ( - Table $\mathbf{1}) \cdot^{1-3}$ received

February 1, 2019

accepted after revision June 6, 2019

published online

September 13, 2019
DOI https://doi.org/

10.1055/s-0039-1694686

ISSN 2348-0548.
Copyright $\odot 2019$ Indian Society of Neuroanaesthesiology and Critical Care
License terms

()(1) $\Theta \circledast$ 
Table 1 Suggested intensive care unit guidelines for the detection, prevention, and management of critical care concerns in acute spinal cord injury

\begin{tabular}{|c|c|c|c|}
\hline Problem & Monitoring ${ }^{a}$ & Finding & Prevention/Management \\
\hline \multicolumn{4}{|l|}{ Neurologic } \\
\hline $\begin{array}{l}\text { Secondary } \\
\text { injury }\end{array}$ & $\begin{array}{l}\text { Spinal cord } \\
\text { assessment }^{\mathrm{b}}\end{array}$ & $\begin{array}{l}\text { Often none } \\
\text { Worsening of neurologic deficits }\end{array}$ & $\begin{array}{l}\text { Spinal precautions } \\
\text { Surgical decompression and stabilization } \\
\text { Avoidance of hypotension, hypoxemia, and anemia } \\
\text { Consider MAP augmentation to } 85-90 \mathrm{~mm} \mathrm{Hg} \text { using } \\
\text { fluids to achieve euvolemia, then vasopressors if } \\
\text { needed }\end{array}$ \\
\hline Pain & $\begin{array}{l}\text { Pain assess- } \\
\text { ments using } \\
\text { NRS-V or BPATc }^{c}\end{array}$ & $\begin{array}{l}\text { Self-reported pain or behavioral } \\
\text { symptoms of pain }\end{array}$ & $\begin{array}{l}\text { Multimodal analgesia } \\
\text { Neuropathic pain therapies } \\
\text { Physical, occupational, speech, and psychiatric therapy }\end{array}$ \\
\hline \multicolumn{4}{|c|}{ Cardiovascular } \\
\hline $\begin{array}{l}\text { Neurogenic } \\
\text { shock }\end{array}$ & $\begin{array}{l}\text { Invasive he- } \\
\text { modynamic } \\
\text { monitoring } \\
\text { TTE } \\
\text { POCUS }\end{array}$ & $\begin{array}{l}\text { Hypotension } \\
\text { Bradycardia } \\
\text { Peripheral vasodilation }\end{array}$ & $\begin{array}{l}\text { Volume resuscitation } \\
\text { Inotropic vasopressors }\end{array}$ \\
\hline $\begin{array}{l}\text { Cardiac } \\
\text { arrhythmia }\end{array}$ & Telemetry & $\begin{array}{l}\text { Sinus bradycardia (most } \\
\text { common) } \\
\text { Atrioventricular blocks } \\
\text { Supraventricular tachycardia }\end{array}$ & $\begin{array}{l}\text { Atropine } \\
\text { Vasopressors with inotropic and chronotropic effects } \\
\text { Temporary transcutaneous or transvenous pacing } \\
\text { Fluid bolus therapy } \\
\text { Abdominal binders } \\
\text { Permanent pacemaker }\end{array}$ \\
\hline $\begin{array}{l}\text { Autonomic } \\
\text { dysreflexia }\end{array}$ & $\begin{array}{l}\text { Telemetry } \\
\text { Arterial pressure } \\
\text { monitoring }\end{array}$ & $\begin{array}{l}\text { Sudden rise in BP } \\
\text { Headache } \\
\text { Pupillary constriction, blurred } \\
\text { vision } \\
\text { Nasal congestion } \\
\text { Anxiety } \\
\text { Diaphoresis, flushing above the } \\
\text { lesion } \\
\text { Piloerection, pale, cool skin } \\
\text { below the lesion }\end{array}$ & $\begin{array}{l}\text { Remove inciting stimulus } \\
\text { Analgesia } \\
\text { IV nitroglycerin }\end{array}$ \\
\hline \multicolumn{4}{|l|}{ Respiratory } \\
\hline $\begin{array}{l}\text { Respiratory } \\
\text { insuffi- } \\
\text { ciency and } \\
\text { atelectasis }\end{array}$ & $\begin{array}{l}\text { Capnography } \\
\text { Cough } \\
\text { assessment }^{\mathrm{d}} \\
\text { ABG } \\
\text { Chest XR }\end{array}$ & $\begin{array}{l}\text { Mild hypoxemia } \\
\text { Diminished breath sounds } \\
\text { Tachypnea } \\
\text { Weak cough } \\
\text { Pulmonary atelectasis or edema } \\
\text { on imaging }\end{array}$ & $\begin{array}{l}\text { Chest physiotherapy and pulmonary hygiene } \\
\text { Cautious nasotracheal suctioning } \\
\text { Noninvasive positive pressure ventilation }\end{array}$ \\
\hline $\begin{array}{l}\text { Ventilatory } \\
\text { failure }\end{array}$ & $\begin{array}{l}\text { Capnography } \\
\text { Cough } \\
\text { assessment } \\
\text { Vital capacity } \\
\text { assessment } \\
\text { every } 12 \text { h } \\
\text { ABG } \\
\text { Chest XR }\end{array}$ & $\begin{array}{l}\text { Hypoxemia } \\
\text { Hypercarbia } \\
\text { Dyspnea } \\
\text { Audible pooling of secretions } \\
\text { Ineffective cough } \\
\text { Paradoxical inward depression } \\
\text { of ribs } \\
\text { Vital capacity }<10-15 \mathrm{~mL} / \mathrm{kg} \\
\text { IBW } \\
\text { Pulmonary atelectasis or edema } \\
\text { on imaging }\end{array}$ & $\begin{array}{l}\text { Chest physiotherapy and pulmonary hygiene } \\
\text { Video laryngoscopy and endotracheal intubation with } \\
\text { MILS } \\
\text { Awake fiberoptic bronchoscope intubation with top- } \\
\text { icalization of the airway in cooperative patients and } \\
\text { nonemergent scenarios } \\
\text { Mechanical ventilation }\end{array}$ \\
\hline
\end{tabular}


Table 1 (continued)

\begin{tabular}{|c|c|c|c|}
\hline Problem & Monitoring ${ }^{a}$ & Finding & Prevention/Management \\
\hline \multicolumn{4}{|l|}{ Hematologic } \\
\hline $\begin{array}{l}\text { Blunt cerebro- } \\
\text { vascular injury }\end{array}$ & $\begin{array}{l}\text { Neurologic } \\
\text { assessments }^{\mathrm{d}} \\
\text { aPTT (if heparin } \\
\text { therapy) }\end{array}$ & $\begin{array}{l}\text { Arterial hemorrhage/epistaxis } \\
\text { Cervical bruit in patients } \\
<50 \text { year of age } \\
\text { Expanding cervical hematoma } \\
\text { Focal neurologic deficit not } \\
\text { explained by head CT } \\
\text { Cerebral infarction on secondary } \\
\text { CT/MRI } \\
\text { Cervical spine fracture of } \\
\text { C1-C3, subluxation, or extend- } \\
\text { ing into the transverse foramen }\end{array}$ & $\begin{array}{l}\text { Antiplatelet or anticoagulation: unfractionated hepa- } \\
\text { rin without bolus and a low aPTT target } \\
\text { ASA } 81 \text { or } 325 \mathrm{mg} \\
\text { Endovascular intervention with stent, coil emboliza- } \\
\text { tion, or lytic therapy } \\
\text { Operative management with primary repair, patch } \\
\text { angioplasty, interposition graft, arterial bypass, or } \\
\text { vessel sacrifice }\end{array}$ \\
\hline DVT & $\begin{array}{l}\text { Extremity } \\
\text { inspection }^{\text {a }} \\
\text { Doppler } \\
\text { ultrasound } \\
\text { aPTT (if heparin } \\
\text { therapy) }\end{array}$ & $\begin{array}{l}\text { Unilateral edema or swelling } \\
\text { with difference in calf or thigh } \\
\text { diameters } \\
\text { Unilateral warmth, erythema }\end{array}$ & $\begin{array}{l}\text { Thromboprophylaxis: Intermittent pneumatic com- } \\
\text { pression devices } \pm \text { graduated compression stockings; } \\
\text { LMWH } \\
\text { Therapeutic unfractionated heparin }\end{array}$ \\
\hline $\begin{array}{l}\text { Pulmonary } \\
\text { embolism }\end{array}$ & $\begin{array}{l}\text { ABG } \\
\text { Temperature } \\
\text { CT angiogram } \\
\text { Perfusion scan } \\
\text { Doppler } \\
\text { ultrasound } \\
\text { TTE } \\
\text { Telemetry } \\
\text { aPTT (if heparin } \\
\text { therapy) }\end{array}$ & $\begin{array}{l}\text { Tachycardia } \\
\text { Fever } \\
\text { Hypoxemia } \\
\text { Widened alveolar-arterial } \mathrm{O}_{2} \\
\text { gradient } \\
\text { Respiratory alkalosis }\end{array}$ & $\begin{array}{l}\text { Respiratory and hemodynamic support } \\
\text { Unfractionated heparin } \\
\text { If anticoagulation is contraindicated, consider inferior } \\
\text { or superior vena cava filter or suprarenal filter based } \\
\text { on DVT location }\end{array}$ \\
\hline \multicolumn{4}{|l|}{ Gastrointestinal } \\
\hline Paralytic ileus & $\begin{array}{l}\text { Auscultation of } \\
\text { bowel sounds } \\
\text { Abdominal XR } \\
\text { CT abdomen } \\
\text { with oral } \\
\text { contrast }\end{array}$ & $\begin{array}{l}\text { Absence of flatus or stool } \\
\text { Hypoactive bowel sounds } \\
\text { Abdominal distention } \\
\text { Nausea or vomiting } \\
\text { High gastric residuals } \\
\text { Dilated loops of bowel on plain } \\
\text { film }\end{array}$ & $\begin{array}{l}\text { NPO } \\
\text { Naso- or orogastric catheter connected to low contin- } \\
\text { uous suction } \\
\text { Manual fecal disimpaction } \\
\text { Stool softeners } \\
\text { Prokinetics }\end{array}$ \\
\hline $\begin{array}{l}\text { Gastroduo- } \\
\text { denal ulcer or } \\
\text { bleeding }\end{array}$ & $\begin{array}{l}\text { CBC } \\
\text { Upper } \\
\text { endoscopy } \\
\text { Electrolytes }\end{array}$ & $\begin{array}{l}\text { Abdominal distention } \\
\text { Hematemesis } \\
\text { Melena } \\
\text { Anemia }\end{array}$ & $\begin{array}{l}\text { Nutritional support } \\
\text { H2-receptor antagonist } \\
\text { PPI }\end{array}$ \\
\hline Pancreatitis & $\begin{array}{l}\text { Temperature } \\
\text { Liver function } \\
\text { tests } \\
\text { Amylase } \\
\text { Lipase } \\
\text { BUN } \\
\text { Electrolytes } \\
\text { CBC } \\
\text { Strict moni- } \\
\text { toring of urine } \\
\text { output } \\
\text { CT abdomen } \\
\text { with IV contrast } \\
\text { Serial bladder } \\
\text { pressures }\end{array}$ & $\begin{array}{l}\text { Abdominal distention } \\
\text { Hypoactive bowel sounds } \\
\text { Fever } \\
\text { Hypoxemia } \\
\text { Hypotension } \\
\text { Scleral icterus } \\
\text { Leukocytosis } \\
\text { Elevated HCT } \\
\text { Elevated BUN } \\
\text { Hypocalcemia } \\
\text { Hyperglycemia } \\
\text { Abdominal compartment } \\
\text { syndrome }\end{array}$ & $\begin{array}{l}\text { Aggressive fluid resuscitation } \\
\text { Correction of electrolytes } \\
\text { Nasojejunal enteral nutrition } \\
\text { Treatment of underlying condition }\end{array}$ \\
\hline $\begin{array}{l}\text { Acute } \\
\text { calculous } \\
\text { cholecystitis }\end{array}$ & $\begin{array}{l}\text { Temperature } \\
\text { Abdominal } \\
\text { ultrasound } \\
\text { Liver function } \\
\text { tests } \\
\text { Amylase }\end{array}$ & $\begin{array}{l}\text { Leukocytosis with left shift } \\
\text { Mild elevation in serum amino- } \\
\text { transferases and amylase } \\
\text { Hyperbilirubinemia } \\
\text { Jaundice } \\
\text { Fever }\end{array}$ & $\begin{array}{l}\text { Supportive care with IV hydration, pain control, NPO, } \\
\text { antibiotics, correction of electrolytes } \\
\text { Percutaneous cholecystotomy or endoscopic gall } \\
\text { bladder drainage } \\
\text { Cholecystectomy if complicated cholecystitis or with } \\
\text { disease progression despite } 3 \mathrm{~d} \text { of biliary drainage }\end{array}$ \\
\hline
\end{tabular}


Table 1 (continued)

\begin{tabular}{|c|c|c|c|}
\hline Problem & Monitoring ${ }^{\mathrm{a}}$ & Finding & Prevention/Management \\
\hline \multicolumn{4}{|c|}{ Genitourinary } \\
\hline $\begin{array}{l}\text { Urinary } \\
\text { retention }\end{array}$ & $\begin{array}{l}\text { Spinal assess- } \\
\text { ment (rectal } \\
\text { tone) } \\
\text { Portable bladder } \\
\text { ultrasound } \\
\text { Urinalysis } \\
\text { Serum BUN/CRT, } \\
\text { electrolytes } \\
\text { Urine electro- } \\
\text { lytes, specific } \\
\text { gravity } \\
\text { Renal ultrasound }\end{array}$ & $\begin{array}{l}\text { Oliguria } \\
\text { Bilateral hydronephrosis } \\
\text { Large postvoid residual urine } \\
\text { volumes }(>500 \mathrm{~mL})\end{array}$ & $\begin{array}{l}\text { Early placement of an indwelling catheter } \\
\text { Suprapubic catheter if urethral trauma precludes } \\
\text { transurethral placement } \\
\text { Clean intermittent catheterization every 4-6 h may be } \\
\text { initiated once resuscitation endpoints are no longer } \\
\text { needed } \\
\text { Oral anticholinergic }\end{array}$ \\
\hline \multicolumn{4}{|c|}{ Infectious disease } \\
\hline UTI & $\begin{array}{l}\text { Urinalysis } \\
\text { Temperature } \\
\text { CBC }\end{array}$ & $\begin{array}{l}\text { Fever } \\
\text { Leukocytosis } \\
\text { Metabolic acidosis } \\
\text { Respiratory alkalosis } \\
\text { Foul-smelling urine } \\
\text { Hematuria } \\
\text { Bacteriuria or funguria }\end{array}$ & $\begin{array}{l}\text { Urine culture obtained by removing the existing in- } \\
\text { dwelling catheter and sampling from a new catheter } \\
\text { Begin empiric antimicrobial treatment immediately } \\
\text { after culture is sampled from a new catheter if high } \\
\text { suspicion } \\
\text { Tailor treatment to the pathogen's susceptibility pat- } \\
\text { tern once identified }\end{array}$ \\
\hline $\begin{array}{l}\text { Pressure } \\
\text { ulcers }\end{array}$ & $\begin{array}{l}\text { Skin integrity } \\
\text { examination } \\
\text { with reposition- } \\
\text { ing (every 2-3 } \\
\text { h), noting down } \\
\text { length, width, } \\
\text { and depth of } \\
\text { any areas of skin } \\
\text { damage }\end{array}$ & $\begin{array}{l}\text { Subdermal injury to areas of } \\
\text { bony prominences: occiput, } \\
\text { shoulder blades, sacrum, coc- } \\
\text { cyx, ankles, heels, chin, ears, } \\
\text { and clavicles under cervical } \\
\text { collar } \\
\text { Warmth, erythema, local } \\
\text { tenderness, purulent discharge, } \\
\text { foul odor with infection of pres- } \\
\text { sure ulcer }\end{array}$ & $\begin{array}{l}\text { Removal of unnecessary immobilization devices } \\
\text { Frequent liberation of areas at risk through pressure } \\
\text { redistribution with proper positioning and support } \\
\text { surfaces } \\
\text { Local wound care with debridement of necrotic tissue } \\
\text { if necessary } \\
\text { Negative-pressure wound therapy } \\
\text { Pain therapy }\end{array}$ \\
\hline Pneumonia & $\begin{array}{l}\text { Temperature } \\
\text { CBC } \\
\text { ABG } \\
\text { Chest XR } \\
\text { Chest CT }\end{array}$ & $\begin{array}{l}\text { Hypoxemia } \\
\text { Increased or purulent secretions } \\
\text { Rhonchi, crackles, reduced } \\
\text { breath sounds } \\
\text { Leukocytosis/leukopenia } \\
\text { New or progressive infiltrate on } \\
\text { imaging } \\
\text { Nonintubated patients: dys- } \\
\text { pnea, tachypnea } \\
\text { Intubated patients: increased } \\
\text { inspiratory pressures }\end{array}$ & $\begin{array}{l}\text { Pneumococcal and influenza vaccination } \\
\text { Sputum or endotracheal aspirate and peripheral blood } \\
\text { sample for culture prior to initiating antibiotics } \\
\text { Empiric antimicrobial therapy tailored to pathogen's } \\
\text { susceptibility pattern once identified } \\
\text { Chest physiotherapy } \\
\text { Pulmonary hygiene } \\
\text { Therapeutic bronchoscopy }\end{array}$ \\
\hline
\end{tabular}

Abbreviations: ABG, arterial blood gas; aPTT, activated partial thromboplastin time; ASA, aspirin; BP, blood pressure; BPAT, Behavioral Pain Assessment Tool; BUN, blood urea nitrogen; CBC, complete blood count; CRT, creatinine; CT, computed tomography; DVT, deep vein thrombosis; HCT, hematocrit; IBW, ideal body weight; IV, intravenous; LMWH, low molecular weight heparin; MAP, mean arterial pressure; MILS, manual in-line stabilization; MRI, magnetic resonance imaging; NPO, nil per os; NRS-V, visually enlarged Numeric Rating Scale; POCUS, point-of-care ultrasound; PPI, proton-pump inhibitor; TTE, transthoracic echocardiogram; UTI, urinary tract infection; XR, radiograph.

aList of suggested monitoring in addition to routine intensive care unit (ICU) measurements of continuous pulse oximetry (SaO2), heart rate (HR), respiratory rate (RR), and cardiac rhythm. BP monitoring is assumed to be noninvasive and, therefore, not continuously measured unless listed otherwise. BP may be measured upon admission of a patient with acute spinal cord injury every 15 minutes $\times 4$, every 30 minutes $\times 2$, every 1 hour $\times 8$, then every 2 hours. Auscultation of heart, lung, and abdomen, palpation of pulses, and inspection of extremities may be performed every 4 hours.

${ }^{b}$ Comprehensive neurologic examination of spinal cord function may be performed upon admission to the ICU and then at least every 12 hours (once each nursing shift) or with a suspected change in examination. Gross motor/sensory spinal cord examination may be performed every 2 hours.

CPain assessments may be performed no less frequently than every 4 hours or as clinically indicated using valid and reliable tools such as the NRS-V in patients who can communicate and the BPAT in patients who cannot communicate. Increases in BP, HR, and RR are not valid indicators for pain but may be used as cues to initiate pain assessment. ${ }^{137-139}$

dNeurologic examination with level of consciousness (using the Glasgow Coma Scale) and cranial nerve assessments may be performed upon admission to the ICU and every 1 hour for 8 hours, then every 2 hours for 16 hours, and every 4 hours thereafter.

eExamples of chest physiotherapy and pulmonary hygiene (formerly referred to as pulmonary toilet) include manual cough assist (quad cough), mechanical insufflation-exsufflation, intrapulmonary percussive ventilation, mucolytics, warm moist air, and intermittent positive-pressure breathing. 
Following insult, the spinal cord enters a state of spinal shock, affecting all functions of the cord below the injury, which can last from a few days up to 4 to 12 weeks, depending on how one defines its resolution. ${ }^{4,5}$ Neurogenic shock is the autonomic manifestation of the spinal shock syndrome. ${ }^{5}$ Supraspinal control of sympathetic output travels in preganglionic neurons from the medulla to the intermediolateral column of the first thoracic to the second lumbar spinal cord segments, with cardioaccelerator fibers located in the first four thoracic segments. ${ }^{6}$ While the feared triad of neurogenic shock-bradycardia, hypotension, and peripheral vasodilation-is more commonly seen with complete lesions of the upper thoracic and cervical cord than in incomplete SCI or thoracolumbar lesions, the entire length of the sympathetic cord supplies innervation to the vasculature, and therefore interruption of descending signals at any level has the capacity to induce vasoplegic shock. ${ }^{7,8}$ Disruption of sympathetic activity reduces vascular resistance in large vascular beds and decreases venous return to the heart. In neurogenic shock, interruption of the positive chronotropic, inotropic, and dromotropic effects on the heart from cardiac sympathetic preganglionic nerves in the upper thoracic segments leaves parasympathetic activity unopposed, resulting in circulatory collapse. ${ }^{9}$ Early judicious fluid bolus therapy restores intravascular volume and cardiac preload, which stimulates atrial stretch receptors to signal the medullary control centers to decrease parasympathetic tone through the vagus nerve to the heart, resulting in an increased heart rate. ${ }^{10}$ Inotropic vasopressors are frequently required to supplement fluid therapy for hemodynamic stabilization in neurogenic shock and to mitigate ischemia and secondary neuronal injury to the vulnerable spinal cord. There is currently no consensus regarding the preferred pharmacological agent; dopamine, norepinephrine, and epinephrine are commonly used vasopressors to treat neurogenic shock. ${ }^{11,12}$ While recent evidence suggests that norepinephrine may be superior to dopamine in increasing spinal cord perfusion pressure with less increases in intrathecal pressure, high-quality data to guide therapeutic endpoints are lacking. ${ }^{13}$

The spinal cord autoregulates its blood flow, maintaining a constant blood supply to support its metabolic demands despite changes in arterial pressure. ${ }^{14}$ At blood pressure values outside the limits of autoregulation, spinal cord perfusion becomes passive to changes in arterial pressure. Trauma to the cord and the ensuing secondary inflammatory response may abolish autoregulatory capacity, with spinal cord perfusion passive at all values of blood pressure. ${ }^{15}$ Experimental data indicate that cord hypoperfusion perpetuates secondary injury. Several investigators have provided class III evidence that mean arterial pressure (MAP) augmentation to 85 to $90 \mathrm{~mm} \mathrm{Hg}$ for the first 5 to 7 days after injury may improve clinical outcome. ${ }^{16-20}$ Based on data from six uncontrolled case series of SCI patients in the 1970s to 1990s, the 2002 guidelines from the American Association of Neurological Surgeons and the Congress of Neurological Surgeons (AANS/ CNS) recommend maintaining a MAP goal of 85 to $90 \mathrm{~mm} \mathrm{Hg}$ for 7 days postinjury. ${ }^{21}$ The investigators chose the duration of MAP augmentation based on experiments in animals. ${ }^{16-18}$ The
2013 AANS/CNS hemodynamic guidelines were essentially unchanged. ${ }^{22}$ Despite the potential harmful consequences of aggressive fluid therapy and vasopressor administration, and the high cost associated with intensive care management during prolonged MAP augmentation, there is unlikely to be prospective controlled data to support these recommendations due to the ethical concerns of lower target comparison groups. ${ }^{23}$ Future study will likely involve controlled trials examining the duration of therapy and mechanism of MAP augmentation (i.e., type of vasopressor, colloid vs. crystalloid, type of crystalloid) to help individualize therapy.

For now, a reasonable hemodynamic management strategy involves the following steps. First, consider all potential causes of hemodynamic instability, including neurogenic shock, myocardial injury, pericardial tamponade, bleeding, tension pneumothorax, and sepsis. Neurogenic shock may coexist alongside hemorrhagic shock from unappreciated bleeding, such as a retroperitoneal hematoma, under-resuscitation preoperatively, or ongoing blood loss postoperatively. Second, expeditiously expand volume with fluid followed by vasopressors to avoid hypotension and optimize cord perfusion. The addition of blood products can be led by blood counts and coagulation profiles. Ideally, fluid and pressor administration should be guided by invasive hemodynamic monitoring, such as pulmonary artery catheterization or pulse contour cardiac output, or by bedside sonography with transthoracic echocardiography or point-of-care ultrasound. Attention should be paid to changes in cardiac output and filling pressures to avoid congestive heart failure. Third, if euvolemia has been approximately achieved with fluids, MAP augmentation to $85 \mathrm{~mm} \mathrm{Hg}$ may be briefly initiated so long as additional fluid or pharmacological interventions do not unfavorably impact other organ systems.

Disruption of autonomic homeostasis in SCI can also lead to fatal cardiac rhythm and conduction abnormalities. Most commonly experienced abnormalities in the acute phase of $\mathrm{SCI}$ are bradyarrhythmias due to parasympathetic predominance, which reflect the level and completeness of injury. ${ }^{2}$ Complete SCI presents as total loss of motor, sensory, and reflex functions, reflecting an absence of communication between the nerves below the lesion and the brain. In an incomplete injury, some signals persist, which manifest in varying degrees of function below the level of injury. ${ }^{24}$ In one series, $100 \%$ of complete cervical SCI patients had persistent resting heart rates less than 60 beats per minute (bpm) and 71\% had heart rates less than $45 \mathrm{bpm}$ for at least 1 day postinjury. ${ }^{1}$ This was compared with $35 \%$ of incomplete cervical SCI patients with heart rates less than 60 bpm and $12 \%$ less than 45 bpm, and $13 \%$ of thoracolumbar SCI patients with heart rates less than $60 \mathrm{bpm}$ and $4 \%$ less than $45 \mathrm{bpm}$. Notably, patients with complete SCI exhibit exquisite sensitivity to vagal stimulation, such that changes in position, increased intrathoracic pressure, suctioning, airway manipulation, and Valsalva maneuvers have all been shown to trigger episodes of severe bradycardia, with some leading to conduction block, sinus pause, and sinus arrest. ${ }^{1,25,26}$ Treatment involves atropine, promoting cardiac preload, and temporary or permanent cardiac pacing. 
Supportive measures include abdominal binders to improve venous return.

According to some authors, the autonomic expression of spinal shock is neurogenic shock, and the autonomic expression correlate of spinal hyperreflexia after recovery from spinal shock is autonomic hyperreflexia. ${ }^{4,5}$ This is a logical comparison because autonomic hyperreflexia, or more commonly referred to as $\mathrm{AD}$, is a group of symptoms typically seen in the chronic phase of SCI after recovery from neurogenic shock and presents as severe paroxysmal hypertension triggered by cutaneous or visceral stimulation below the lesion. ${ }^{27}$ The earliest reported case of $\mathrm{AD}$ was 4 days after injury, but an initial or recurrent episode can present at any time during the life of an SCI patient. ${ }^{28,29} \mathrm{AD}$ is more common and more severe in patients with complete and upper cord lesions than in those with incomplete and lower cord lesions.

AD is thought to be mediated by an upregulation of adrenoceptor number, an increase in catecholamine sensitivity, and the loss of inhibitory descending sympathetic control. ${ }^{27}$ Triggered by a strong sensory input below the level of the lesion, peripheral nerves carry the disturbing message to the spinal cord. Afferent signals then travel up and down the intact portion of the cord and paraspinal sympathetic ganglion, evoking a massive reflex sympathetic surge from the thoracolumbar sympathetic nerves. This causes widespread vasoconstriction, most significantly in the splanchnic vasculature, and release of epinephrine and norepinephrine into the systemic circulation through stimulation of the adrenal medulla. Aortic and carotid baroreceptors convey the message of this hypertensive crisis through cranial nerves IX and X to the nucleus of the solitary tract (NTS) in the medulla. The NTS projects to the cardioinhibitory area containing the nucleus ambiguus and dorsal motor nucleus of the vagus, which results in strong parasympathetic outflow. The NTS also relays to the caudal ventrolateral medulla (CVLM), which, when activated, inhibits the rostral ventrolateral medulla (RVLM). ${ }^{6}$ Bulbospinal presympathetic neurons in the RVLM travel through the cord and typically release glutamatergic excitatory impulses to the sympathetic preganglionic neurons in the intermediolateral column from T1 to L2. With a functional baroreceptor reflex, the NTS and CVLM quiet this sympathoexcitatory output from the RVLM. ${ }^{6}$ In SCI patients, however, these signals can only travel as far as the level of neurologic injury. The parasympathetic activity and descending supraspinal efforts to suppress the sympathetic activity are ineffective in reducing blood pressure. Above the level of the injury, parasympathetic activity dominates, and patients display pupillary constriction, diaphoresis, and flushing. Below the level of injury, unfettered sympathetic activity leads to piloerection and pale, cool skin. ${ }^{27}$ Presynaptic sympathetic nerves from T5 to T9 form the greater splanchnic nerve, which, through the celiac ganglion, supplies most of the splanchnic vascular bed. $\mathrm{AD}$ is less commonly seen in patients with lesions below T6 (and rarely below T10) because at least some signals descend far enough to modulate splanchnic tone. ${ }^{9}$

A rise in systolic blood pressure greater than $20 \mathrm{~mm} \mathrm{Hg}$ from baseline is used as the diagnosis of AD. ${ }^{30}$ Treatment is to identify and relieve the patient of the offending agent.
Noxious stimulus from bladder distention is more easily addressed than pain from wounds and skeletal fractures. In the ICU setting, simply providing additional analgesia may be effective for acute AD. In refractory cases, a rapid-onset short-acting vasodilator such as nitroglycerin is a preferred agent to avoid hypotension after AD resolves. ${ }^{27,31}$

\section{Respiratory}

Acute injury to the cervical and thoracic spinal cord affects respiratory mechanics, ventilatory control, and bronchial reactivity, all of which play a large role in early and late morbidity and mortality. ${ }^{32,33}$ Respiratory insufficiency may be apparent immediately or develop over time, depending on the severity and anatomic level of injury and the duration of spinal shock. ${ }^{34}$ Flaccid paralysis of the muscles below the level of the injury associated with the first phase of spinal shock may last several hours to several weeks. ${ }^{4}$ Complete injury above $\mathrm{C} 3$ produces acute ventilatory failure and apneic respiratory arrest. Complete and incomplete injuries at C3 through C5 typically require airway protection and mechanical ventilation during the first few days to weeks. As the initial flaccidity of the diaphragm and inspiratory accessory muscles transitions to spasticity, and additional accessory muscles are recruited, spontaneous ventilation may be sufficient for liberation from mechanical ventilation. With lesions at C6 through C8 and paralysis of intercostal muscles, negative intrathoracic pressure during inspiration can lead to a paradoxical inward depression of the ribs. This mechanical imbalance results in increased work of breathing, distal airway collapse, atelectasis, and inefficient ventilation. Airway secretions accumulate through increased production and decreased clearance secondary to impaired cough. ${ }^{33,35}$ Pneumonia is seen in more than $20 \%$ of SCI patients and is a common cause of mortality in this population. ${ }^{34}$ Patients with an injury to the T12 level or lower should have no respiratory impairment; despite this, traumatic SCI patients frequently suffer from rib fractures, pulmonary contusions, hemopneumothorax, or other injuries to the thoracic cage that lead to acute respiratory failure requiring intubation and mechanical ventilation. Close respiratory monitoring and aggressive pulmonary hygiene and chest physiotherapy should be undertaken early in intubated patients. ${ }^{36}$ Of note, even minor increases in the vagal tone that are normally counteracted by sympathetic influences, such as during bronchocarinal stimulation from suctioning, may precipitate severe bradyarrhythmias leading to sinus arrest., ${ }^{1,25}$ Readily available intravenous atropine and preoxygenation prior to suctioning are recommended. ${ }^{25}$

Several studies have investigated the timing and clinical predictors of tracheostomy in patients with acute cervical SCI. ${ }^{37-40}$ Risk factors for tracheostomy after traumatic cervical SCI include American Spinal Injury Association (ASIA) Impairment Scale (AIS) ${ }^{24}$ grade A and B, upper cervical SCI (C4 or higher), Glasgow Coma Scale 8, thoracic injury, and respiratory complications. ${ }^{41}$ Tracheostomy should be performed shortly after hemodynamic stability is obtained in patients with complete injury to the high cervical spine (C3 or higher). Tracheostomy placement both prior to and immediately 
after anterior cervical spine surgery has been shown to be safe and does not increase the risk of surgical wound infection. ${ }^{42,43}$ Success in remaining without invasive airway support varies in patients with injuries from C3 to C6. Early tracheostomy (less than 7 days after injury) has a clear benefit in patients who are likely to require prolonged mechanical ventilation, such as shorter length of ICU stay and decreased laryngotracheal complications. ${ }^{44}$ Cord swelling and bleeding within the first few days of injury may cause loss of up to one AIS level, making this period of time high risk for intubation but probably too soon to predict the need for longterm mechanical ventilation. However, retrospective studies suggest that early tracheostomy is beneficial in reducing the duration of mechanical ventilation in SCI patients irrespective of the level of injury. ${ }^{44,45}$

Though not yet prospectively studied in SCI patients, interest has grown in the use of ultrasound as a noninvasive, bedside approach for evaluating diaphragm function to help predict which patients will become ventilator dependent. $^{46,47}$ Diagnostic criteria for diaphragmatic paralysis include paradoxical movement and/or significantly reduced dome excursion using $\mathrm{M}$ mode at the subcostal windows or reduced diaphragm thickening during inspiration using a linear high-frequency transducer at the zone of apposition. ${ }^{46,48}$ This is best assessed during maximal inspiratory maneuvers in spontaneously breathing nonintubated patients or during spontaneous breathing trials in intubated patients. More prospective studies are needed to determine the best methods for predicting extubation success, ventilatory dependency, and the appropriate timing of tracheostomy in SCI patients.

\section{Hematological}

In patients with traumatic SCI, concomitant blunt cerebrovascular injury (BCVI) is an independent risk factor for increased morbidity and mortality. ${ }^{49-51}$ Cervical SCI is highly associated with extracranial carotid and vertebral artery injury. Forceful neck flexion, hyperextension, and rotation during motor vehicle crashes account for almost one-half of BCVI. ${ }^{52,53}$ However, upper cervical vertebral fractures sustained during low-energy ground-level falls account for one-third of BCVI in patients aged 65 years and older. ${ }^{54}$ Impingement of the carotid or vertebral artery against bone, stretching or twisting of the vessel, or laceration by bone fragments produces an intimal tear. Intimal defects provide a pathway for blood to enter the layers of the artery wall, which may cascade into one or more mechanisms of injury. ${ }^{55}$ Simple exposure of subendothelial collagen initiates platelet aggregation and thrombus formation, which may lead to stenosis, occlusion, or embolization. Less commonly, a subintimal dissection may occur and advance cranially, with further risk of luminal narrowing or vessel occlusion. Similarly, traumatic pseudoaneurysm from subadventitial expansion of blood may develop, which also carries a risk of vessel compression, thrombus formation, or enlargement and rupture. Complete transection of the artery occurs rarely, resulting in intra- or extracranial hemorrhage or arteriovenous fistula. ${ }^{52}$

Although evidence surrounding screening protocols for BCVI is still evolving, computed tomography (CT) angiography (CTA) using a comprehensive screening criterion is currently recommended as part of the initial trauma imaging assessment. ${ }^{56-59}$ While digital subtraction angiography is considered the gold standard modality for diagnosing BCVI, it is not without risk, and availability depends on local expertise. ${ }^{60}$ Suggested expanded screening criteria include both signs and symptoms of BCVI (i.e., arterial bleeding, cervical bruit, expanding hematoma, focal neurologic deficit, neurologic examination incongruous with head CT findings, stroke on secondary CT or magnetic resonance imaging [MRI]), as well as high-risk injury mechanisms and fracture patterns in asymptomatic patients (i.e., cervical spine fractures, traumatic brain injury [TBI] with thoracic injury, and Le Fort II or III facial fractures, among others). ${ }^{57}$ Fracture patterns with the greatest risk of carotid and vertebral artery injury in traumatic SCI patients include cervical spine fractures involving $\mathrm{C} 1$ to $\mathrm{C} 3$, cervical fracture subluxations, and cervical fractures extending to the foramen transversarium. ${ }^{61}$ Patients with BCVI may present to the hospital during their initial trauma with signs of stroke and corresponding neurologic deficits already in progress or the effects of BCVI may be masked by concurrent traumatic brain, craniofacial, or cervical spine injuries. ${ }^{62}$ More commonly, patients with BCVI experience an asymptomatic period before the onset of stroke, which typically ranges from 10 to 72 hours. ${ }^{57,62-65}$ The hope is to identify and initiate treatment during this latent period before devastating ischemic neurologic deficits occur.

Once a diagnosis of BCVI is made, determining the grade of injury aids in clinical communication between multidisciplinary providers and helps guide treatment and prognosis. ${ }^{59}$ In the commonly used scale proposed by Biffl et al, ${ }^{66}$ grade I represents a mild intimal injury or dissection with less than 25\% luminal narrowing. Grade II represents a dissection with a raised intimal flap or vessel thrombosis, resulting in luminal narrowing greater than $25 \%$. Grade III is a dissecting aneurysm or a pseudoaneurysm. Grade IV represents complete vessel occlusion or thrombosis, and grade $\mathrm{V}$ represents vessel transection with active extravasation or hemodynamically significant arteriovenous fistula. ${ }^{67}$ Treatment may include medical therapy with antiplatelets or anticoagulation as early as safely possible, endovascular intervention, or operative repair..$^{59}$ The treatment strategy depends on the site(s) of vessel injury, grade of injury, extent of neurologic symptoms, local expertise, and associated injuries. There have been no randomized trials conducted in BCVI patients comparing antiplatelet therapy with anticoagulation therapy, evaluating drugs within each class (i.e., unfractionated vs. low-molecular weight heparin) or assessing the safest time to begin antithrombotic therapy after multi-system trauma. ${ }^{68}$ Unfractionated heparin infusion with a low partial thromboplastin time goal and no bolus is preferred in the acute setting as it is reversible and can be monitored easily in the ICU. ${ }^{68}$ Several observational studies suggest that benefits of early antithrombotic treatment of BCVI may outweigh any potential harm to other traumatic injuries, including spinal cord, traumatic brain, and solid organ injury. ${ }^{68-71}$ Studies suggest that in SCI patients with concurrent TBI and intracerebral hemorrhage, antithrombotic therapy may be safely 
initiated for BCVI within 72 hours of injury, after head CT demonstrates improvement or stability. ${ }^{68,70,71}$ Additional evidence indicates that if SCI patients with BCVI require surgical decompression, antithrombotic therapy may be held perioperatively and safely initiated 72 hours after surgery. ${ }^{70}$ However, individual clinical circumstances should inevitably dictate management with all responsible providers informed and in agreement with the care plan.

Operative management is indicated for surgically accessible grade II, III, and V BCVI according to major trauma society guidelines. ${ }^{58,59}$ Many lesions, however, are not surgically accessible, especially vertebral artery injuries, since they involve vessels at the base of the skull. Although there are no randomized trials, successful endovascular therapy for surgically inaccessible grade II, III, and V BCVI has been demonstrated in several small case series. ${ }^{72-74}$ While endovascular treatment may prevent new or recurrent stroke, dual antiplatelet therapy required for stent patency increases the risk of hemorrhage in trauma patients.

Grade I injuries (mild intimal irregularities) typically resolve with antithrombotic therapy alone and have a low stroke risk..$^{75}$ Initiating early antithrombotic therapy with heparin is similarly recommended in grade II injuries (dissection); however, endovascular stenting may be indicated if arterial dissections progress to near-occlusion. ${ }^{76}$ Grade III injuries (pseudoaneurysm) also benefit from early therapy with heparin. Operative repair with patch angioplasty, interposition graft, or bypass procedures or endovascular intervention with stent or coil embolization is warranted if a pseudoaneurysm is symptomatic or expanding. ${ }^{77,78}$ Grade IV injuries (occlusion) are associated with high mortality, and antithrombotic therapy with heparin is recommended as early as possible. There are no data demonstrating benefit from surgical or endovascular therapy for grade IV injuries. ${ }^{79,80}$ Grade V injuries (transection) are also associated with high rates of stroke and mortality. An expanding neck hematoma from active extravasation or rupture should be controlled with direct pressure until surgical control is obtained or until endovascular angioembolization if the injury is inaccessible. Repeat imaging with CTA 7 to 10 days after the injury (or sooner if new neurologic deficits manifest) is recommended for all injury grades. This repeat image is intended to confirm or repudiate the diagnosis of BCVI in cases where the initial CTA displayed vasospasm or was misinterpreted. ${ }^{56}$

Venous thromboembolism (VTE) is another potentially life-threatening risk in both the acute and chronic phases of SCI. Vasomotor tone is initially lost in acute SCI, and dependent extremities become edematous. Venous stasis predisposes patients to deep vein thrombosis, pulmonary embolism, stroke, and other vascular complications. While vasomotor tone may eventually improve, SCI patients remain at a high risk of VTE throughout their lives due to limited movement. A large nationwide retrospective cohort study from Taiwan revealed that SCI patients have a 2.46 -fold adjusted hazard ratio of deep vein thrombosis and a 1.57 -fold adjusted hazard ratio of pulmonary embolism compared with that of the general population. ${ }^{81}$ The Consortium for Spinal Cord Medicine provides grade 1C (strong recommendation, low-quality evidence) support for mechanical thromboprophylaxis with intermittent pneumatic compression devices (with or without graduated compression stockings) as soon as feasible after acute $\mathrm{SCI}$ and chemical thromboprophylaxis with low molecular weight heparin once there is no evidence of bleeding. ${ }^{82}$

\section{Gastrointestinal, Genitourinary, and Infectious Disease}

Spinal shock after acute SCI affects intrinsic enteric nervous system control, which may result in an array of gastrointestinal (GI) maladies, such as paralytic ileus, gastroduodenal ulceration and hemorrhage, pancreatitis, and cholecystitis. ${ }^{83}$ GI injury in acute $\mathrm{SCI}$ is further exacerbated by steroid administration, opioid therapy, and antibiotics. Sensory deficits in acute SCI contribute to a delay in diagnosis, and therefore routine monitoring of electrolytes, hepatic enzymes, coagulation parameters, and blood counts is warranted. ${ }^{84}$ Early implementation of bowel care may reduce the risk of catastrophic GI injury during the acute phase of $\mathrm{SCl}$ and includes digital or manual evacuation of stool; H2-receptor antagonists, proton-pump inhibitors, and enteral nutrition (as soon as safely possible) for gastric ulceration prophylaxis; and nasogastric suctioning to reduce ileus. ${ }^{36}$ Prokinetic agents such as metoclopramide and erythromycin may be necessary to overcome refractory dilatation. ${ }^{85,86}$ Urinary retention is common and requires bladder catheterization in the acute phase of injury to avoid bladder distension injury and chronic management to avoid AD. Patients with acute SCI are also at an increased risk of infection, with the urinary tract being the most common site. ${ }^{87}$ Patients are highly prone to decubitus ulcers, which can progress to deep infections and sepsis. Even in the acute phase of SCI, patients must be turned routinely and assessed by caregivers to avoid development, or start early treatment of ulcers. Sepsis is a leading cause of death in all ICU patients, and SCI patients are no exception. The causes of death found to have the greatest impact on reduced life expectancy over the past 45 years in patients enrolled in the United States National SCI Database were pneumonia and septicemia. ${ }^{88,89}$

Thermoregulatory dysfunction is common in $\mathrm{SCI}$ due to unbalanced autonomic homeostasis and impaired sudomotor and vasomotor responses, leading to poikilothermia. Hypothalamic regulation of sympathetically mediated vasodilation and hidrosis is disrupted after upper $\mathrm{SCl}$, leading to ineffective heat dissipation in response to warm ambient temperatures and hyperthermia. ${ }^{90}$ Conversely, large portions of insentient skin and loss of skeletal muscle activity delay or prevent hypothalamic initiation of shivering in response to cold ambient environments. Combined with impaired sympathetically mediated peripheral vasoconstriction, cervical SCI patients are highly vulnerable to hypothermia from ineffective heat conservation..$^{91}$ Accidental hypothermia is associated with multiple harmful effects, including coagulopathy, metabolic acidosis, cardiac arrhythmias, and impaired tissue oxygen delivery. Hypothermia also decreases the cardiovascular response to catecholamines and increases the risk of wound infection, pneumonia, and sepsis. Moreover, fever in response to infection may be masked in an SCI patient with subnormal baseline temperatures. ${ }^{92}$ In some cases, euthermia may be a sign of infection. 
Close temperature monitoring is warranted, with adjustment of room temperature, cooling with ice packs, or use of forcedair warming devices, as needed, to maintain normothermia.

\section{Use of Steroids in Medical Management}

The use of corticosteroids to potentially attenuate the inflammatory cascade contributing to secondary injury in $\mathrm{SCI}$ continues to be of great debate. The National Acute Spinal Cord Injury Study (NASCIS) trials were a series of large randomized controlled experiments assessing the utility of methylprednisolone (MP) therapy. ${ }^{93-96}$ Results of these trials suggested that when initiated within 3 hours of injury, MP therapy for 24 hours (bolus followed by continuous infusion) improved motor function. When initiated between 3 and 8 hours of injury, MP therapy for 48 hours was associated with a greater improvement in outcomes than the 24-hour duration, however with greater risk of infection and significantly increased rates of severe sepsis. Moreover, these trials were criticized for multiple methodological flaws. ${ }^{97}$ Since these trials, investigators have mostly demonstrated no significant long-term benefit and instead found an increased risk of GI bleeding and other adverse events. ${ }^{98,99}$ For these reasons, in 2013, the AANS/CNS released a level 1 (standard) recommendation against using MP for acute management of SCI. ${ }^{100}$

\section{Neuroprotection}

Multiple neuroprotective agents are currently being evaluated as adjunctive medical treatment in patients with acute SCI. Riluzole is an oral glutamate antagonist first approved by the U.S. Food and Drug Administration as a disease-modifying agent in patients with amyotrophic lateral sclerosis. ${ }^{101}$ Riluzole's anti-glutaminergic actions are postulated to blunt excitotoxicity at neuronal sites of injury. A phase I trial showed significant motor improvement at 90 days postinjury in patients with cervical SCI who received 14 days of riluzole beginning within 12 hours of injury. ${ }^{102}$ The Riluzole in Acute Spinal Cord Injury Study (RISCIS) is an ongoing multicenter phase IIb/III randomized, placebo-controlled trial to assess its efficacy and safety in acute cervical SCI. ${ }^{103,104}$ Minocycline is a second-generation tetracycline antibiotic that has anti-inflammatory properties and has been shown to reduce apoptosis and minimize lesion size in animal models. ${ }^{105} \mathrm{~A}$ phase II single-center, randomized, placebo-controlled trial of patients with acute SCI treated with intravenous minocycline for 7 days demonstrated safety and a tendency toward improved motor recovery at 1 year in patients with cervical lesions. ${ }^{106}$ The results of the phase III trial, Minocycline in Acute Spinal Cord Injury (MASC), have yet to be published. ${ }^{107}$ Hypothermia has also been found to facilitate neurologic improvement in both animal models and human studies

Table 2 Recommended neuropathic pain therapies for spinal cord injury and their mechanism of action

\begin{tabular}{|c|c|}
\hline First $^{\mathrm{a}}$ & High-quality evidence and a strong recommendation \\
\hline $\begin{array}{l}\text { Gabapentinoids } \\
\text { (pregabalin, gabapentin) }\end{array}$ & G-protein coupled receptor antagonist leading to inhibition of glutamate release \\
\hline $\begin{array}{l}\text { Tricyclic antidepressants } \\
\text { (amitriptyline) }\end{array}$ & $\begin{array}{l}\text { Increase } 5 \mathrm{HT} \text { and NE at axon terminal through uptake inhibition; block ACH, adrenergic, and } \\
\text { histamine receptors }\end{array}$ \\
\hline Second & High- or moderate-quality evidence and a strong recommendation \\
\hline Tramadol & Mu-opioid receptor agonist and weakly increases $5 \mathrm{HT}$ and NE through reuptake inhibition \\
\hline Lamotrigine & Na-channel antagonist leading to inhibition of glutamate release \\
\hline Third & High- or moderate-quality evidence and a weak recommendation \\
\hline $\begin{array}{l}\text { Transcranial direct cur- } \\
\text { rent stimulation } \\
\pm \text { visual illusion }\end{array}$ & $\begin{array}{l}\text { Modulates cortical excitability from aberrant nociceptive impulses generated by the injured } \\
\text { spinal somatosensory circuity and misinterpreted by the brain as pain } \\
\text { Correction of the incongruence between motor output and sensory feedback, and normalization } \\
\text { of cortical somatosensory representation maps, induced by the visual input of movements of the } \\
\text { paralyzed limbs }\end{array}$ \\
\hline Fourth & Moderate- or low-quality evidence and a weak recommendation \\
\hline $\begin{array}{l}\text { Transcutaneous electric } \\
\text { nerve stimulation }\end{array}$ & $\begin{array}{l}\text { Afferent input to the periaqueductal gray, rostral ventromedial medulla, and spinal cord by } \\
\text { stimulation of large diameter } A \beta \text { fibers using electrical current activates descending inhibitory } \\
\text { systems to reduce hyperalgesia }\end{array}$ \\
\hline Oxycodone & $\begin{array}{l}\text { Potent } \mu \text {-opiate receptor agonist mediates analgesia through changes in the perception of pain } \\
\text { at the spinal cord ( } \mu 2-, \text { delta-, kappa-receptors) and higher levels in the CNS ( } \mu 1 \text { - and kappa 3-re- } \\
\text { ceptors). Opioids modulate channel activity resulting in hyperpolarization and reduced neuronal } \\
\text { excitability. Opioid receptors are also coupled with G-protein receptors. Opioid binding inhibits } \\
\text { adenylate cyclase, which decreases intracellular cAMP that modulates the release of nociceptive } \\
\text { neurotransmitters such as substance P, GABA, dopamine, acetylcholine, and norepinephrine }\end{array}$ \\
\hline $\begin{array}{l}\text { Dorsal root entry zone } \\
\text { lesioning }\end{array}$ & $\begin{array}{l}\text { Selectively destroys the nociceptive fibers grouped in the lateral bundle of the dorsal rootlet, } \\
\text { the excitatory medial part of the Lissauer tract, and the deafferented hyperactive neurons of the } \\
\text { dorsal horn }\end{array}$ \\
\hline
\end{tabular}

Abbreviations: 5HT, 5-hydroxytryptamine (serotonin); ACH, acetylcholine; cAMP, cyclic adenosine monophosphate; CNS, central nervous system; GABA, gaba-aminobutyric acid; Na, sodium; NE, norepinephrine.

aTreatment categorization determined by an expert panel based on the quality of scientific evidence and strength of recommendations, with consideration of clinical experience, side-effect profile, and effectiveness in other neuropathic pain populations. ${ }^{140}$ 
through a variety of mechanisms such as reducing inflammation and metabolism and preservation of the blood-spinal cord barrier. ${ }^{108}$ A multicenter, randomized, case-controlled study called Acute Rapid Cooling for Traumatic Injuries of the Cord (ARCTIC) is underway to determine the safety profile and efficacy of modest $\left(33.5^{\circ} \mathrm{C}\right)$ intravascular hypothermia within 6 hours of cervical SCI for a duration of 48 hours followed by 24 hours of controlled rewarming compared with maintenance of normothermia $\left(37^{\circ} \mathrm{C}\right)$ for 72 hours. ${ }^{109}$

\section{Recovery and Rehabilitation}

Rehabilitation therapy: After definitive treatment of the SCI and the management of associated conditions in the hospital, patients greatly benefit from transfer to a rehabilitation unit for continued neurologic recovery. Here they learn techniques for mobilization and self-care to help improve functional status. In high-resource settings, rehabilitation typically begins early within the ICU and involves physical, occupational, and respiratory therapists; speech and language pathologists; dietitians; and rehabilitation psychologists. ${ }^{10,111}$

Pain therapy: Neuropathic pain negatively impacts quality of life, mood, and ability to participate in rehabilitation and recovery efforts in the ICU and beyond. Unfortunately, despite multiple pain therapies (- Table 2), approximately 50 to $60 \%$ of SCI patients experience persistent, significant pain after injury. ${ }^{112,113}$ As a consequence of pain and disability, approximately $22 \%$ of SCI patients suffer from depression. ${ }^{114,115}$ This can be managed with physical and psychological therapy, antidepressants, and pain control. ${ }^{116,117}$ Additionally, patients suffer from spasticity, which also results in pain. ${ }^{118}$ Baclofen is the primary spasmolytic used in management, which may be administered orally or through an intrathecal pump. Early oral baclofen administration ( 1 day after $\mathrm{SCI}$ ) has been reported; however, further study is warranted to determine the efficacy and appropriate timing of its use in the ICU. ${ }^{119}$ Tizanidine and benzodiazepines are also commonly used agents to treat spasticity, with the latter more commonly used in acute settings. For focal areas of spasticity, botulinum toxin injections have been used, with some success after SCI. ${ }^{120}$ Lastly, physical treatments, such as stretching, passive cycling, static weight bearing, and electrical stimulation have been shown to both reduce spasticity and improve motor function. ${ }^{121}$

Prognostication of recovery: Prognostication for patients with SCI involves estimates of both neurologic and functional recovery. Neurologic recovery is inversely proportional to the severity of injury. According to a systematic review of 51 articles on clinical predictors of neurologic outcome, functional status, and survival after SCI, approximately 10 to $15 \%$ of patients with complete SCI eventually regained some neurologic function and converted to incomplete status. ${ }^{122}$ Among those with AIS grade B, one-third did not recover any additional function, one-third moved to AIS $\mathrm{C}$, and another third moved to AIS D or E over the course of follow-up. For AIS C patients, approximately $70 \%$ converted to AIS D or E. Patients with a better initial AIS grade and those with lower lesions typically have better long-term functional recovery.

Neuroregeneration: An active area of investigation in $\mathrm{SCI}$ is neuroregeneration to augment recovery strategies. ${ }^{123}$ Fibroblast growth factor (FGF) has shown to have neuroprotective and neuroregenerative properties through stimulation of axonal growth, inflammation reduction, and astrocyte activation. Due to its size, FGF has limited penetration through intact blood-spinal cord barrier. SUN13837 is a small molecule that acts as an FGF mimetic and works as an agonist at FGF receptors. The phase I/II randomized controlled ASCENTASCI (Asubio Spinal Cord Early Neurorecovery Treatment for Acute Spinal Cord Injury) study to determine the safety, efficacy, and pharmacokinetics of giving intravenous SUN13837 within 12 hours of acute cervical SCI for no less than 7 and no more than 28 days showed promising results with nonsignificant trends in functional improvement at 16 weeks. ${ }^{124}$

As a result of inflammation, myelin debris, and glial scar formation, several growth inhibitory proteins are released during acute SCI. These act to impede axon regeneration partly through the activation of Rho, a family of small intracellular GTPases that regulate the formation of focal adhesion, stress fibers, and cytoskeleton organization. ${ }^{125}$ Upon activation, Rho signals a cascade of events, leading to apoptosis, collapse of axonal growth cones, and failure of axon regeneration. Inactivation of Rho and of Rho kinases promotes axon regeneration and functional recovery after $\mathrm{SCI}$ in rats and mice. ${ }^{125} \mathrm{VX}-210$, also referred to as BA-210 or Cethrin, is a derivative of $\mathrm{C} 3$ transferase, a toxin produced by Clostridium botulinum that inhibits Rho proteins by ADP-ribosylation in the effector binding domain of the GTPase. ${ }^{126} \mathrm{~A}$ phase I/ Ila open-label, unblinded trial of dural application ranging from 0.3 to $9 \mathrm{mg}$ of Cethrin during surgery in complete (AIS A) SCI patients performed within the first 7 days after injury observed conversions to AIS C or D in $31 \%$ of cervical patients and in $6 \%$ of thoracic patients at 1 -year follow-up. Of cervical SCI patients receiving a $3 \mathrm{mg}$ dose of intradural Cethrin, $66 \%$ improved to AIS C or better. There were no drug-related serious adverse events. ${ }^{126} \mathrm{VX}-210$ is now under investigation in the multicenter, phase IIb/III randomized, placebo-controlled Spinal Cord Injury Rho Inhibition Investigation (SPRING) trial to evaluate its efficacy and safety in acute cervical SCI and its effect on functional recovery at 6 months postinjury using an upper extremity motor score. ${ }^{127}$

Ongoing studies assessing the utility of cell-based therapies to promote neuronal regeneration include trials of autologous Schwann cell ${ }^{128,129}$ and oligodendrocyte progenitor cell ${ }^{130}$ transplantation for remyelination, clinical trials of olfactory ensheathing cell transplantation for regeneration and functional reconnection, ${ }^{131}$ a phase II trial of allogeneic human CNS stem cell intramedullary transplantation, ${ }^{132}$ and a phase II/III trial of autologous bone marrow derived mesenchymal stem cell transplantation. ${ }^{133}$ Studies investigating biomaterials such as spinal scaffolds to guide axonal growth, and techniques such as cerebrospinal fluid drainage to reduce pressure, improve cord perfusion, and reduce ischemia are also underway. ${ }^{134-136}$ 


\section{Conclusion}

Patients require comprehensive, interdisciplinary care in the ICU to combat the potentially catastrophic multisystem sequelae of SCI. Patients who survive the initial hospitalization greatly benefit from early rehabilitation but need continuous care. There is an ongoing development of molecular agents to assist in neuroprotection and neuroregeneration to help recover function postinjury. Management of SCI will continue to evolve to individualize care and help improve long-term outcomes.

\section{Funding}

Kathryn Rosenblatt, MD, MHS, is supported by the Stimulating and Advancing ACCM Research (StAAR) Mentored Research Grant from the Johns Hopkins Department of Anesthesiology and Critical Care Medicine.

\section{Conflict of Interest}

None declared.

\section{References}

1 Lehmann KG,Lane JG,Piepmeier JM,Batsford WP. Cardiovascular abnormalities accompanying acute spinal cord injury in humans: incidence, time course and severity. J Am Coll Cardiol 1987; 10 (1):46-52

2 Manogue M, Hirsh DS, Lloyd M. Cardiac electrophysiology of patients with spinal cord injury. Heart Rhythm 2017;14(6):920-927

3 Furlan JC, Fehlings MG. Cardiovascular complications after acute spinal cord injury: pathophysiology, diagnosis, and management. Neurosurg Focus 2008;25(5):E13

4 Ditunno JF, Little JW, Tessler A, Burns AS. Spinal shock revisited: a four-phase model. Spinal Cord 2004;42(7):383-395

5 Atkinson PP, Atkinson JL. Spinal shock. Mayo Clin Proc 1996;71(4):384-389

6 Guyenet PG. The sympathetic control of blood pressure. Nat Rev Neurosci 2006;7(5):335-346

7 Taylor MP, Wrenn P, O'Donnell AD. Presentation of neurogenic shock within the emergency department. Emerg Med J 2017;34(3):157-162

8 Guly HR, Bouamra O, Lecky FE; Trauma Autabledit and Research Network. The incidence of neurogenic shock in patients with isolated spinal cord injury in the emergency department. Resuscitation 2008;76(1):57-62

9 Biering-Sørensen F, Biering-Sørensen T, Liu N, Malmqvist L, Wecht JM, Krassioukov A. Alterations in cardiac autonomic control in spinal cord injury. Auton Neurosci 2018; 209:4-18

10 Jones JJ. The Bainbridge reflex. J Physiol 1962;160(2):298-305

11 Ruiz IA, Squair JW, Phillips AA, et al. Incidence and natural progression of neurogenic shock after traumatic spinal cord injury. J Neurotrauma 2018;35(3):461-466

12 Inoue T, Manley GT, Patel N, Whetstone WD. Medical and surgical management after spinal cord injury: vasopressor usage, early surgerys, and complications. J Neurotrauma 2014;31(3):284-291

13 Altaf F, Griesdale DE, Belanger L, et al. The differential effects of norepinephrine and dopamine on cerebrospinal fluid pressure and spinal cord perfusion pressure after acute human spinal cord injury. Spinal Cord 2017;55(1):33-38

14 Hickey R, Albin MS, Bunegin L, Gelineau J. Autoregulation of spinal cord blood flow: is the cord a microcosm of the brain? Stroke 1986;17(6):1183-1189
15 Mortazavi MM, Verma K, Harmon OA, et al. The microanatomy of spinal cord injury: a review. Clin Anat 2015;28(1):27-36

16 Levi L, Wolf A, Belzberg H. Hemodynamic parameters in patients with acute cervical cord trauma: description, intervention, and prediction of outcome. Neurosurgery 1993;33(6):1007-1016, discussion 1016-1017

17 Wolf A, Levi L, Mirvis S, et al. Operative management of bilateral facet dislocation. J Neurosurg 1991;75(6):883-890

18 Vale FL, Burns J, Jackson AB, Hadley MN. Combined medical and surgical treatment after acute spinal cord injury: results of a prospective pilot study to assess the merits of aggressive medical resuscitation and blood pressure management. J Neurosurg 1997;87(2):239-246

19 Hawryluk G, Whetstone W, Saigal R, et al. Mean arterial blood pressure correlates with neurological recovery after human spinal cord injury: analysis of high frequency physiologic data. J Neurotrauma 2015;32(24):1958-1967

20 Dakson A, Brandman D, Thibault-Halman G, Christie SD. Optimization of the mean arterial pressure and timing of surgical decompression in traumatic spinal cord injury: a retrospective study. Spinal Cord 2017;55(11):1033-1038

21 Hadley MN, Walters BC, Grabb PA, et al. Blood pressure management after acute spinal cord injury. Neurosurgery 2002;50(3, Suppl):S58-S62

22 Ryken TC, Hurlbert RJ, Hadley MN, et al. The acute cardiopulmonary management of patients with cervical spinal cord injuries. Neurosurgery 2013;72(3 Suppl 2):84-92

23 Readdy WJ, Whetstone WD, Ferguson AR, et al. Complications and outcomes of vasopressor usage in acute traumatic central cord syndrome. J Neurosurg Spine 2015;23(5):574-580

24 Kirshblum S, Waring W III. Updates for the International Standards for Neurological Classification of Spinal Cord Injury. Phys Med Rehabil Clin N Am 2014;25(3):505-517,vii

25 Mathias CJ. Bradycardia and cardiac arrest during tracheal suction--mechanisms in tetraplegic patients. Eur J Intensive Care Med 1976;2(4):147-156

26 van Lieshout JJ, Imholz BP, Wesseling KH, Speelman JD, Wieling W. Singing-induced hypotension: a complication of a high spinal cord lesion. Neth J Med 1991;38(1-2):75-79

27 Eldahan KC, Rabchevsky AG. Autonomic dysreflexia after spinal cord injury: systemic pathophysiology and methods of management. Auton Neurosci 2018;209:59-70

28 Krassioukov AV, Furlan JC, Fehlings MG. Autonomic dysreflexia in acute spinal cord injury: an under-recognized clinical entity. J Neurotrauma 2003;20(8):707-716

29 McKinley WO, Jackson AB, Cardenas DD, DeVivo MJ. Longterm medical complications after traumatic spinal cord injury: a regional model systems analysis. Arch Phys Med Rehabil 1999;80(11):1402-1410

30 Alexander MS, Biering-Sorensen F, Bodner D, et al. International standards to document remaining autonomic function after spinal cord injury. Spinal Cord 2009;47(1):36-43

31 Caruso D, Gater D, Harnish C. Prevention of recurrent autonomic dysreflexia: a survey of current practice. Clin Auton Res 2015;25(5):293-300

32 Slack RS, Shucart W. Respiratory dysfunction associated with traumatic injury to the central nervous system. Clin Chest Med 1994;15(4):739-749

33 Dicpinigaitis PV, Spungen AM, Bauman WA, Absgarten A, Almenoff PL. Bronchial hyperresponsiveness after cervical spinal cord injury. Chest 1994;105(4):1073-1076

34 Grossman RG, Frankowski RF, Burau KD, et al. Incidence and severity of acute complications after spinal cord injury. J Neurosurg Spine 2012;17(1 Suppl):119-128

35 Bhaskar KR, Brown R, O'Sullivan DD, Melia S, Duggan M, Reid L. Bronchial mucus hypersecretion in acute quadriplegia. Macromolecular yields and glycoconjugate composition. Am Rev Respir Dis 1991;143(3):640-648 
36 Consortium for Spinal Cord Medicine. Early acute management in adults with spinal cord injury: a clinical practice guideline for health-care professionals.J Spinal Cord Med 2008;31(4):403-479

37 Leelapattana P, Fleming JC, Gurr KR, Bailey SI, Parry N, Bailey CS. Predicting the need for tracheostomy in patients with cervical spinal cord injury. J Trauma Acute Care Surg 2012;73(4):880-884

38 Lee DS, Park CM, Carriere KC, Ahn J. Classification and regression tree model for predicting tracheostomy in patients with traumatic cervical spinal cord injury. Eur Spine J 2017;26(9):2333-2339

39 Tanaka J, Yugue I, Shiba K, Maeyama A, Naito M. A study of risk factors for tracheostomy in patients with a cervical spinal cord injury. Spine 2016;41(9):764-771

40 Beom JY, Seo HY. The need for early tracheostomy in patients with traumatic cervical cord injury. Clin Orthop Surg 2018;10(2):191-196

41 Wang Y, Guo Z, Fan D, et al. A meta-analysis of the influencing factors for tracheostomy after cervical spinal cord injury. BioMed Res Int 2018;2018:5895830

42 Galeiras R, Mourelo M, Bouza MT, et al. Risk analysis based on the timing of tracheostomy procedures in patients with spinal cord injury requiring cervical spine surgery. World Neurosurg 2018;116:e655-e661

43 Lozano CP, Chen KA, Marks JA, Jenoff JS, Cohen MJ, Weinstein MS. Safety of early tracheostomy in trauma patients after anterior cervical fusion. J Trauma Acute Care Surg 2018;85(4):741-746

44 Romero J, Vari A, Gambarrutta C, Oliviero A. Tracheostomy timing in traumatic spinal cord injury. Eur Spine J 2009;18(10):1452-1457

45 Guirgis AH, Menon VK, Suri N, et al. Early versus late tracheostomy for patients with high and low cervical spinal cord injuries. Sultan Qaboos Univ Med J 2016;16(4):e458-e463

46 Kim WY, Suh HJ, Hong SB, Koh Y, Lim CM. Diaphragm dysfunction assessed by ultrasonography: influence on weaning from mechanical ventilation. Crit Care Med 2011;39(12):2627-2630

47 Vázquez RG, Sedes PR, Fariña MM, Marqués AM, Velasco MEF, Respiratory management in the patient with spinal cord injury. Biomed Res Int 2013; 2013:168757

48 Fayssoil A, Behin A, Ogna A, et al. Diaphragm: pathophysiology and ultrasound imaging in neuromuscular disorders. J Neuromuscul Dis2018;5(1):1-10

49 Weber CD, Lefering R, Kobbe P, et al; Trauma Register DGU. Blunt cerebrovascular artery injury and stroke in severely injured patients: an international multicenter analysis. World J Surg 2018;42(7):2043-2053

50 Schicho A, Luerken L, Meier R, et al. Incidence of traumatic carotid and vertebral artery dissections: results of cervical vessel computed tomography angiogram as a mandatory scan component in severely injured patients. Ther Clin Risk Manag 2018; $14: 173-178$

51 Stein DM, Boswell S, Sliker CW, Lui FY, Scalea TM. Blunt cerebrovascular injuries: does treatment always matter? J Trauma 2009;66(1):132-143, discussion 143-144

52 Fleck SK, Langner S, Baldauf J, Kirsch M, Kohlmann T, Schroeder HWS. Incidence of blunt craniocervical artery injuries: use of whole-body computed tomography trauma imaging with adapted computed tomography angiography. Neurosurgery 2011;69(3):615-623,discussion623-624

53 Biffl WL, Moore EE, Offner PJ, et al. Optimizing screening for blunt cerebrovascular injuries. Am J Surg 1999;178(6):517-522

54 Anto VP, Brown JB, Peitzman AB, et al. Blunt cerebrovascular injury in elderly fall patients: are we screening enough? World J Emerg Surg 2018;13:30

55 Foreman PM, Harrigan MR. Blunt traumatic extracranial cerebrovascular injury and ischemic stroke. Cerebrovasc Dis Extra 2017;7(1):72-83
56 Brommeland T, Helseth E, Aarhus M, et al. Best practice guidelines for blunt cerebrovascular injury (BCVI) Scand J Trauma Resusc Emerg Med 2018;26(1):90

57 Geddes AE, Burlew CC, Wagenaar AE, et al. Expanded screening criteria for blunt cerebrovascular injury: a bigger impact than anticipated. Am J Surg 2016;212(6):1167-1174

58 Bromberg WJ, Collier BC, Diebel LN, et al. Blunt cerebrovascular injury practice management guidelines: the Eastern Association for the Surgery of Trauma. J Trauma 2010;68(2):471-477

59 Shafafy R, Suresh S, Afolayan JO, Vaccaro AR, Panchmatia JR. Blunt vertebral vascular injury in trauma patients: ATLS ${ }^{\circledR}$ recommendations and review of current evidence. J Spine Surg 2017;3(2):217-225

60 Anaya C, Munera F, Bloomer CW, Danton GH, Caban K. Screening multidetector computed tomography angiography in the evaluation on blunt neck injuries: an evidence-based approach. Semin Ultrasound CT MR 2009;30(3):205-214

61 Cothren CC, Moore EE, Ray CE Jr, Johnson JL, Moore JB, Burch JM. Cervical spine fracture patterns mandating screening to rule out blunt cerebrovascular injury. Surgery 2007;141(1):76-82

62 Burlew CC, Sumislawski JJ, Behnfield CD, et al. Time to stroke: A Western Trauma Association multicenter study of blunt cerebrovascular injuries. J Trauma Acute Care Surg 2018;85(5):858-866

63 Krajewski LP, Hertzer NR. Blunt carotid artery trauma: report of two cases and review of the literature. Ann Surg 1980;191(3):341-346

64 Mokri B, Piepgras DG, Houser OW. Traumatic dissections of the extracranial internal carotid artery. J Neurosurg 1988;68(2):189-197

65 Cothren CC, Moore EE, Ray CE Jr, et al. Screening for blunt cerebrovascular injuries is cost-effective. Am J Surg 2005;190(6):845-849

66 Biffl WL, Moore EE, Offner PJ, Brega KE, Franciose RJ, Burch JM. Blunt carotid arterial injuries: implications of a new grading scale. J Trauma 1999;47(5):845-853

67 Foreman PM, Griessenauer CJ, Kicielinski KP, et al. Reliability assessment of the Biffl Scale for blunt traumatic cerebrovascular injury as detected on computer tomography angiography. J Neurosurg 2017;127(1):32-35

68 Cothren CC, Biffl WL, Moore EE, Kashuk JL, Johnson JL. Treatment for blunt cerebrovascular injuries: equivalence of anticoagulation and antiplatelet agents. Arch Surg 2009;144(7):685-690

69 Shahan CP, Magnotti LJ, McBeth PB, Weinberg JA, Croce MA, Fabian TC. Early antithrombotic therapy is safe and effective in patients with blunt cerebrovascular injury and solid organ injury or traumatic brain injury. J Trauma Acute Care Surg 2016;81(1):173-177

70 Callcut RA, Hanseman DJ, Solan PD, et al. Early treatment of blunt cerebrovascular injury with concomitant hemorrhagic neurologic injury is safe and effective. J Trauma Acute Care Surg 2012;72(2):338-345, discussion345-346

71 McNutt MK, Kale AC, Kitagawa RS, et al. Management of blunt cerebrovascular injury (BCVI) in the multisystem injury patient with contraindications to immediate anti-thrombotic therapy. Injury 2018;49(1):67-74

72 Jindal G, Fortes M, Miller T, Scalea T, Gandhi D. Endovascular stent repair of traumatic cervical internal carotid artery injuries. J Trauma Acute Care Surg 2013;75(5):896-903

73 Edwards NM, Fabian TC, Claridge JA, Timmons SD, Fischer PE, Croce MA. Antithrombotic therapy and endovascular stents are effective treatment for blunt carotid injuries: results from longtermfollowup. J Am Coll Surg 2007;204(5):1007-1013,discussion1014-1015

74 Shahan CP, Sharpe JP, Stickley SM, et al. The changing role of endovascular stenting for blunt cerebrovascular injuries. J Trauma Acute Care Surg 2018;84(2):308-311 
75 Biffl WL, Ray CE Jr, Moore EE, et al. Treatment-related outcomes from blunt cerebrovascular injuries: importance of routine follow-up arteriography. Ann Surg 2002;235(5):699-706,discussion706-707

76 Spanos K, Karathanos C, Stamoulis K, Giannoukas AD. Endovascular treatment of traumatic internal carotid artery pseudoaneurysm. Injury 2016;47(2):307-312

77 Mei Q, Sui M, Xiao W, et al. Individualized endovascular treatment of high-grade traumatic vertebral artery injury. Acta Neurochir (Wien) 2014;156(9):1781-1788

78 Garg K, Rockman CB, Lee V, et al. Presentation and management of carotid artery aneurysms and pseudoaneurysms. J Vasc Surg 2012;55(6):1618-1622

79 Cogbill TH, Moore EE, Meissner M, et al. The spectrum of blunt injury to the carotid artery: a multicenter perspective. J Trauma 1994;37(3):473-479

80 Lauerman MH, Feeney T, Sliker CW, et al. Lethal now or lethal later: the natural history of Grade 4 blunt cerebrovascular injury. J Trauma Acute Care Surg 2015;78(6): 1071-1074,discussion1074-1075

81 Chung WS, Lin CL, Chang SN, Chung HA, Sung FC, Kao CH. Increased risk of deep vein thrombosis and pulmonary thromboembolism in patients with spinal cord injury: a nationwide cohort prospective study. Thromb Res 2014;133(4):579-584

82 Prevention of Venous Thromboembolism in Individuals with Spinal Cord Injury: Clinical Practice Guidelines for Health Care Providers, 3rd ed. Consortium for Spinal Cord Medicine. Top Spinal Cord Inj Rehabil 2016;22(3):209-240

83 Chung EA, Emmanuel AV. Gastrointestinal symptoms related to autonomic dysfunction following spinal cord injury. Prog Brain Res 2006;152:317-333

84 Sarıfakıoğlu B, Afşar SI, Yalbuzdağ ŞA, Ustaömer K, Ayaş S. Acute abdominal emergencies and spinal cord injury; our experiences: a retrospective clinical study. Spinal Cord 2014;52(9):697-700

85 Segal JL, Milne N, Brunnemann SR, Lyons KP. Metoclopramide-induced normalization of impaired gastric emptying in spinal cord injury. Am J Gastroenterol 1987;82(11):1143-1148

86 Clanton LJ Jr, Bender J. Refractory spinal cord injury induced gastroparesis: resolution with erythromycin lactobionate, a case report. J Spinal Cord Med 1999;22(4):236-238

87 Garcia-Arguello LY, O'Horo JC, Farrell A, et al. Infections in the spinal cord-injured population: a systematic review. Spinal Cord 2017;55(6):526-534

88 Devivo MJ. Epidemiology of traumatic spinal cord injury: trends and future implications. Spinal Cord 2012;50(5):365-372

89 DeVivo MJ. Sir Ludwig Guttmann Lecture: trends in spinal cord injury rehabilitation outcomes from model systems in the United States: 1973-2006. Spinal Cord 2007;45(11):713-721

90 Handrakis JP, Trbovich M, Hagen EM, Price M. Thermodysregulation in persons with spinal cord injury: case series on use of the autonomic standards. Spinal Cord Ser Cases 2017;3:17086

91 Khan S, Plummer M, Martinez-Arizala A, Banovac K. Hypothermia in patients with chronic spinal cord injury. J Spinal Cord Med 2007;30(1):27-30

92 Biering-Sørensen F, Alexander MS, van Asbeck FWA, Donovan W, Krassioukov A, Post MWM. Version 1.1 of the international spinal cord injury skin and thermoregulation function basic data set. Spinal Cord 2017;55(6):566-569

93 Bracken MB, Collins WF, Freeman DF, et al. Efficacy of methylprednisolone in acute spinal cord injury. JAMA 1984;251(1):45-52

94 Bracken MB, Shepard MJ, Collins WF, et al. A randomized, controlled trial of methylprednisolone or naloxone in the treatment of acute spinal-cord injury. Results of the Second National Acute Spinal Cord Injury Study. N Engl J Med 1990;322(20):1405-1411
95 Bracken MB, Holford TR. Effects of timing of methylprednisolone or naloxone administration on recovery of segmental and long-tract neurological function in NASCIS 2. J Neurosurg 1993;79(4):500-507

96 Bracken MB, Shepard MJ, Holford TR, et al. Administration of methylprednisolone for 24 or 48 hours or tirilazadmesylate for 48 hours in the treatment of acute spinal cord injury. Results of the Third National Acute Spinal Cord Injury Randomized Controlled Trial. National Acute Spinal Cord Injury Study. JAMA 1997;277(20):1597-1604

97 Nesathurai S. Steroids and spinal cord injury: revisiting the NASCIS 2 and NASCIS 3 trials. J Trauma 1998;45(6):1088-1093

98 Chikuda H, Yasunaga H, Takeshita K, et al. Mortality and morbidity after high-dose methylprednisolone treatment in patients with acute cervical spinal cord injury: a propensity-matched analysis using a nationwide administrative database. Emerg Med J 2014;31(3):201-206

99 Evaniew N, Noonan VK, Fallah N, et al; RHSCIR Network. Methylprednisolone for the treatment of patients with acute spinal cord injuries: a propensity score-matched cohort study from a Canadian multi-center spinal cord injury registry. J Neurotrauma 2015;32(21):1674-1683

100 Hurlbert RJ, Hadley MN, Walters BC, et al. Pharmacological therapy for acute spinal cord injury. Neurosurgery 2013;72(3, Suppl 2):93-105

101 Dharmadasa T, Kiernan MC. Riluzole, disease stage and survival in ALS. Lancet Neurol 2018;17(5):385-386

102 Grossman RG, Fehlings MG, Frankowski RF, et al. A prospective, multicenter, phase I matched-comparison group trial of safety, pharmacokinetics, and preliminary efficacy of riluzole in patients with traumatic spinal cord injury. J Neurotrauma 2014;31(3):239-255

103 Fehlings MG, Nakashima H, Nagoshi N, Chow DSL, Grossman RG, Kopjar B. Rationale, design and critical end points for the Riluzole in Acute Spinal Cord Injury Study (RISCIS): a randomized, double-blinded, placebo-controlled parallel multicenter trial. Spinal Cord 2016;54(1):8-15

104 ClinicalTrials.gov. Riluzole in Spinal Cord Injury Study. Available at: https://clinicaltrials.gov/ct2/show/NCT01597518. Accessed May 2019

105 Wells JE, Hurlbert RJ, Fehlings MG, Yong VW. Neuroprotection by minocycline facilitates significant recovery from spinal cord injury in mice. Brain 2003;126(Pt 7):1628-1637

106 Casha S, Zygun D, McGowan MD, Bains I, Yong VW, Hurlbert RJ. Results of a phase II placebo-controlled randomized trial of minocycline in acute spinal cord injury. Brain 2012;135(Pt 4):1224-1236

107 ClinicalTrials.gov. Minocycline in Acute Spinal Cord Injury (MASC). Available at: https://clinicaltrials.gov/ct2/show/ NCT01828203. Accessed April 2019

108 Wang J, Pearse DD. Therapeutic hypothermia in spinal cord injury: the status of its use and open questions. Int J Mol Sci 2015;16(8):16848-16879

109 ClinicalTrials.gov. Systemic Hypothermia in Acute Cervical Spinal Cord Injury. Available at: https://clinicaltrials.gov/ct2/ show/NCT02991690. Accessed April 2019

110 Sandrow-Feinberg HR, Houlé JD. Exercise after spinal cord injury as an agent for neuroprotection, regeneration and rehabilitation. Brain Res 2015;1619:12-21

111 Rozeboom N, Parenteau K, Carratturo D. Rehabilitation starts in the intensive care unit. Crit Care Nurs Q 2012;35(3):234-240

112 Burke D, Fullen BM, Stokes D, Lennon O. Neuropathic pain prevalence following spinal cord injury: a systematic review and meta-analysis. Eur J Pain 2017;21(1):29-44

113 Finnerup NB, Norrbrink C, Trok K, et al. Phenotypes and predictors of pain following traumatic spinal cord injury: a prospective study. J Pain 2014;15(1):40-48 
114 Williams R, Murray A. Prevalence of depression after spinal cord injury: a meta-analysis. Arch Phys Med Rehabil 2015;96(1):133-140

115 Müller R, Landmann G, Béchir M, et al. Chronic pain, depression and quality of life in individuals with spinal cord injury: mediating role of participation. J Rehabil Med 2017;49(6):489-496

116 Widerström-Noga E. Neuropathic pain and spinal cord injury: phenotypes and pharmacological management. Drugs 2017;77(9):967-984

117 Guy SD, Mehta S, Harvey D, et al. The CanPain SCI Clinical Practice Guideline for Rehabilitation Management of Neuropathic Pain after Spinal Cord: recommendations for model systems of care. Spinal Cord 2016;54(Suppl 1):S24-S27

118 Finnerup NB. Neuropathic pain and spasticity: intricate consequences of spinal cord injury. Spinal Cord 2017;55(12):1046-1050

119 Holtz KA, Szefer E, Noonan VK, Kwon BK, Mills PB. Treatment patterns of in-patient spasticity medication use after traumatic spinal cord injury: a prospective cohort study. Spinal Cord 2018;56(12):1176-1183

120 Marciniak C, Rader L, Gagnon C. The use of botulinum toxin for spasticity after spinal cord injury. Am J Phys Med Rehabil 2008;87(4):312-317,quiz 318-320, 329

121 D’Amico JM, Condliffe EG, Martins KJ, Bennett DJ, Gorassini MA. Recovery of neuronal and network excitability after spinal cord injury and implications for spasticity. Front Integr Nuerosci 2014;8:36

122 Wilson JR, Cadotte DW, Fehlings MG. Clinical predictors of neurological outcome, functional status, and survival after traumatic spinal cord injury: a systematic review. J Neurosurg Spine $2012 ; 17(1$, Suppl):11-26

123 Ahuja CS, Fehlings M. Concise review: bridging the gap: novel neuroregenerative and neuroprotective strategies in spinal cord injury. Stem Cells Transl Med 2016;5(7):914-924

124 Levinson B, Lee J, Chou H, Maiman D. SUN13837 in treatment of acute spinal cord injury, the ASCENT-ASCI Study. ClinNeurolNeurosc 2017;2(1):1

125 Dubreuil CI, Winton MJ, McKerracher L. Rho activation patterns after spinal cord injury and the role of activated Rho in apoptosis in the central nervous system. J Cell Biol 2003;162(2):233-243

126 Fehlings MG, Theodore N, Harrop J, et al. A phase I/IIa clinical trial of a recombinant Rho protein antagonist in acute spinal cord injury. J Neurotrauma 2011;28(5):787-796

127 Fehlings MG, Kim KD, Aarabi B, et al. Rho inhibitor VX-210 in acute traumatic subaxial cervical spinal cord injury: design of the SPinal Cord Injury Rho INhibitionInvestiGation (SPRING) clinical trial. J Neurotrauma 2018;35(9):1049-1056
128 Anderson KD, Guest JD, Dietrich WD, et al. Safety of autologous human schwann cell transplantation in subacute thoracic spinal cord injury. J Neurotrauma 2017;34(21):2950-2963

129 ClinicalTrials.gov. The Safety of ahSC in Chronic SCI with Rehabilitation. Available at; https://clinicaltrials.gov/ct2/show/ NCT02354625. Accessed May 2019

130 Dose Escalation Study of AST-OPC1 in Spinal Cord Injury, Available at: https://clinicaltrials.gov/ct2/show/NCT02302157. Accessed May 2019

131 Watzlawick R, Rind J, Sena ES, et al. Olfactory ensheathing cell transplantation in experimental spinal cord injury: effect size and reporting bias of 62 experimental treatments: a systematic review and meta-analysis. PLoS Biol 2016;14(5):e1002468

132 Study of Human Central Nervous System (CNS) Stem Cell Transplantation in Cervical Spinal Cord Injury, Available at: https://clinicaltrials.gov/ct2/show/NCT02163876. Accessed May 2019

133 ClinicalTrials.gov. Safety and Efficacy of Autologous Mesenchymal Stem Cells in Chronic Spinal Cord Injury. Available at: https://clinicaltrials.gov/ct2/show/NCT01676441. Accessed May 2019

134 Theodore N, Hlubek R, Danielson J, et al. First human implantation of a bioresorbable polymer scaffold for acute traumatic spinal cord injury: a clinical pilot study for safety and feasibility. Neurosurgery 2016;79(2):E305-E312

135 ClinicalTrials.gov. Functional Neural Regeneration Collagen Scaffold Transplantation in Acute Spinal Cord Injury Patients. Available at: https://clinicaltrials.gov/ct2/show/ NCT02510365. Accessed May 2019

136 ClinicalTrials.gov. Cerebrospinal Fluid Drainage (CSFD) in Acute Spinal Cord Injury. Available at: https://clinicaltrials. gov/ct2/show/NCT02495545. Accessed May 2019

137 Chanques G, Viel E, Constantin JM, et al. The measurement of pain in intensive care unit: comparison of 5 self-report intensity scales: Pain 2010; 151 (3):711-721

138 Devlin JW, Skrobik Y, Gélinas C, et al. Clinical practice guidelines for the prevention and management of pain, agitation/ sedation, delirium, immobility, and sleep disruption in adult patients in the ICU. Crit Care Med 2018; 46 (9):e825-e873

139 Gélinas C, Puntillo KA, Levin P, Azoulay E. The behavior pain assessment tool for critically ill adults: a validation study in 28 countries. Pain 2017; 158 (5):811-821

140 Guy SD, Mehta S, Casalino A, et al. The CanPain SCI clinical practice guidelines for rehabilitation management of neuropathic pain after spinal cord: recommendations for treatment. Spinal Cord 2016; 54 (S1):S14-S23 